\title{
Managing the Barriers to Entrepreneural Endeavours in a Developing Economy as Nigeria
}

\author{
${ }^{1}$ Dr. Mary Ijeoma Marire. ${ }^{2}$ Dr. Barnabas Ekpere Nwankwo. ${ }^{3}$ Dr. Ngozi Sydney- \\ Agbor.

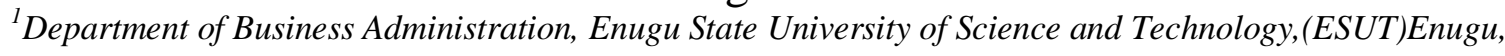 \\ Nigeria. \\ ${ }^{2}$ Department of Psychology, Caritas University Enugu, Nigeria. \\ ${ }^{3}$ Department of Psychology (Industrial/Organizational Unit), Imo State University Owerri, Nigeria.
}

\begin{abstract}
Entrepreneurship combines the passion of a social mission with an image of business commonly associated with the high-tech or low-tech business ventures. Entrepreneurship has long been perceived as one of the significant factors leading to development. This research examined the barriers that pose as obstacles to the pursuit of entrepreneurial endeavours in Nigeria. The objective of the research is to have an insight into common daily activities that relate to all aspects of our lives. The research is based on quantitative research, using a questionnaire of 27 items for data collection. Descriptive data and statistical analyses were presented to identify and assess barriers to entrepreneurship in Nigeria. The research provided valuable insight into the factors affecting entrepreneurial inclination in developing countries like Ngeria. The findings of this research suggested that there are important barriers to entrepreneurship in developing countries. In Nigeria, the most significant of those barriers are: lack of social network, lack of external stability, lack of risk aversion technique, and lack of good business environment that is conducive to entrepreneurship. The significance of this research lies in the fact that it fills an important gap in the literature of entrepreneurial development, offering deeper understanding of the barriers to entrepreneurship in a developing nation, like Nigeria.
\end{abstract}

Keywords: endeavour, entrepreneurship, barriers, developing, business development, nigeria

\section{Introduction}

Though entrepreneurship has always existed as an economic activity, it is a somewhat novel concept to researchers and academics in developing countries. With entrepreneurs now numbering nearly 400 million in 54 countries (GEM Global report, 2011), interest in investigating entrepreneurial inclination is on the rise. Consequently, research on entrepreneurship is quickly gaining ground since there is so much to learn about the antecedents of entrepreneurship, and its effects on the individual, community, and nation. Such research becomes more important, even more challenging, when focusing on developing nations, where investigative studies are much fewer and accurate data is, to a large extent, unavailable. Due to bad economic trends, salvaging the economy of any nation is of paramount importance, hence, the need for encouragement of entrepreneurship and its education.Entrepreneurship education aims at preparing people, especially youths, to be responsible, enterprising individuals who become entrepreneurs or entrepreneurial thinkers and who contribute to economic development and sustainable communities. Entrepreneurship is not something new or strange in the world of business, especially in a country like Nigeria. One could either be an entrepreneur on a small scale, medium scale or a large scale, which mostly involves corporate bodies. With the level of unemployment in the nation today, entrepreneurship seems to be taking its toll. There are several programmes and initiatives brought up by the government to educate the people and promote entrepreneurship. For instance, Nigerian Youth Entrepreneurship Development Programme (NYEDP), Youth Enterprise with Innovation in Nigeria (YouWIN!), Risxcel Youth Entrepreneurship Award Scheme (Nigeria), are some of such programmes that encourage and promote youth entrepreneurship in Nigeria. FATE Foundation and Leadership, Effectiveness, Accountability, and Professionalism (LEAP) Africa are big organizations that promote entrepreneurship. These programmes give established and aspiring entrepreneurs opportunities to gain insights into the world of business. Analysts have said that the Nigerian youths fractions over half of Nigeria's population with most of them unemployed with low skills level, little wonder the sky-rocketing crime rates which has become the bane of the society. Inadequate capital; unhealthy and unstable economic environment; fear of the people to take risk on entrepreneurial activities and government policies are identified among other factors hindering entrepreneurship in the country.

Most of the available researches on entrepreneurship focus on advanced economies rather than on developing ones (Krueger et al., 2000). Though this poses a challenge to researchers, it also presents an opportunity to investigate a variety of variables related to entrepreneurship for the purpose of reaching a 
paradigm that is working in developing nations. According to Fayolie, (2003) entrepreneurship is a gobal phenomenon, which has spured the interest of students as a choice in career as traditional professional employment in big business is gradually declining. I think excellent entrepreneurship education consist of three ingredients;

1) Creativity-creating all kinds of ideas.

2) Innovation-find the value in selection ideas.

3) Entrepreneurship-develop a business from the innovation ideas.

\section{Objectives}

The objectives which includes how to manage the barriers to entrepreneurship endeavors in a developing Economy: Nigeria

To have an insight on how risk aversion can lead to risky endeavors.

To study the economic stability to entrepreneurial inclination.

To consider social networking as a daily activity that relates to entrepreneurial inclination.

\section{Theoretical Background}

An entrepreneur is defined by longman's dictionary as someone who starts a new business or arranges business deals in order to make money, often in a way that involves financial risks. An entrepreneur can also be defined as a person who organizes and manages a business, assuming risk for the sake of potential return (Mariotti, 2012). This implies' that risk, though undesirable, is an essential element of any entrepreneurial venture, where the return can be immense and multi-faceted.

\section{Consequences of Entrepreneurship}

At the macro-level, entrepreneurship seems to be stimulated by government practices that facilitate and encourage new business startups. Such practices may include tax reductions tariff and quota incentives, fewer regulations governing startups in certain industries, regional offices that offer business consultancy services, among others, in an effort to support and encourage entrepreneurial endeavours. Aldrich,(1990) suggests that governments can stimulate entrepreneurs by reducing taxes, offering incentives, minimizing businesses in developing consultancy services to them. In q supportive business environment, new businesses in developing nations can strive and gain sustainability.

Entrepreneurship Education: The consortium for entrepreneurship education provides teachers with information to help students of all ages find entrepreneurial opportunities. The site includes teaching materials, classroom activities, and transparency masters.

\section{Barriers To Entrepreneurship}

Two schools of thought dominate research related to barriers to entrepreneurship, one highlighting psychological variables deterring entrepreneurial endeavours, and the other accentuating variables related to the business environment. Taormina and Lao (2007), shows, that budding entrepreneurs faces psychological issues such as achievement striving and optimism. Indeed, micro-Ievel environment forces should not be understand. Factors in the external environment, can potentially influence the start-up decision (Aldrich, 2000). Just as favourable external factors can be considered conducive to entrepreneurship, unfavourable external factors can be powerful barriers to it.

The model underlying this study suggests that independent variables related to the psychological school, the business environment, and environmental stability, have a significant effect on entrepreneurial inclination. Figure 1 presents the conceptual framework underlying this study. 


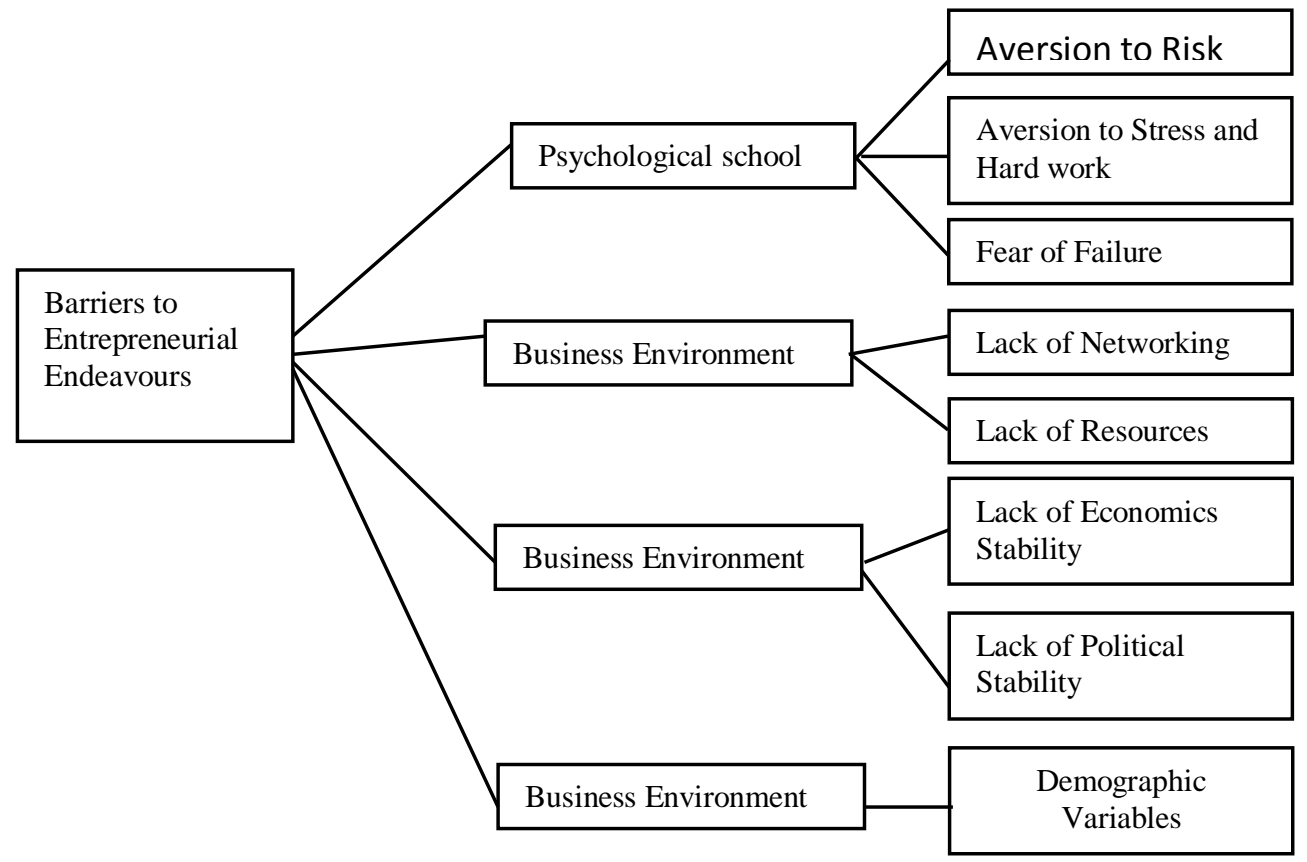

Figure:1 Source: Conceptual Framework model.

\section{Research Methods}

A sample of 101 respondents participated in the study of assessing entrepreneurial inclination. The sample is made up of college students, employees, unemployed individuals, and entrepreneurs. Such a wide variety of respondents provided a better understanding of people's perceptions about starting a business since anyone of them can be an existing or potential entrepreneur. The questionnaires were distributed to people who came to purchase wares at Shoprite in Enugu by the researchers who waited for the respondents to complete the surveys and then collected them in person, thus obtaining a 100\% response rate. The choice of Shoprite is because of its strategic location and high patronage that it receives daily, making it a rallying point of people who come either to make purchases or site seeing. The study lasted for 2 days. The survey instrument consisted of a total of 27 items, 7 of which were related to demographics, and 20 were related to individual perceptions, measured on a 5point Likert scale, ranging from 1 (strongly disagree) to 5 (strongly agree). It is important to note that these 20 items measured 8 factors which are: social network, fear of failure, business environment, external stability, lack of resources, aversion to stress and hard work, aversion to risk, lack of training and lack of preparation.

Reliability measures the internal consistency of the scale, and Cronbach's alpha is used as an indication of reliability. An alpha $>0.7$ is recommended (Nunnally, 1978), but an alpha $>0.6$ is acceptable for exploratory research (Hair et al., 1995). For this study, Cronbach's alpha was 0.61 which is acceptable since this study is exploratory. The data was subjected to several tests. Analysis of variance was run on demographic variables to see if they have any influence on entrepreneurial inclination. Factor Analysis was conducted to identify the small number of factors that may have some influence on entrepreneurship inclination. Later regression analysis was run on the identified factors to assess their importance in predicting entrepreneurial inclination.

\section{Data Analysis and Findings \\ Profile of the Respondents}

The age group of the respondents was relatively young, $56.4 \%$ of the respondents were between 20 and 29 years of age, $32.7 \%$ were between 30 and 39 years old, while only $8.9 \%$ were above 40 years old. The data for gender showed that $60.4 \%$ of the respondents were males, while only $39.6 \%$ were female. Most of the respondents $(67.3 \%)$ were single, while only a third $(30.7 \%)$ were married. Over $66 \%$ of all respondents had a college degree, and about one third $(33.7 \%)$ had only a high school degree. The employment status of the respondents well reflected the population, as over a quarter of the respondents $(26.7 \%)$ were unemployed. An almost similar percentage $(22.8 \%)$ was self-employed, while $46.5 \%$ were employed in organizations belonging to either the private or the public sector. Most of the respondent $(46.5 \%)$ earned a monthly income between $\$ 500$ and $\$ 1000$, while a slightly smaller percentage (32.7\%) earned between $\$ 1,000$ and $\$ 3,000$. Almost $12 \%$ of respondents earn below $\$ 500$. Table 1 clearly presents the demographic characteristics of the respondents. 


\section{Entrepreneurial Inclination Cross-Tabulated With Demographic Variables}

Respondents were highly inclined to start their own business as the mean for this dimension reached 3.55 on a 5-point Likert scale. Moreover, almost two thirds of the respondents (59\%) expressed an inclination to start a business, and answered strongly agreed or agree. Only $27 \%$ of the respondents said they were disinclined (Strongly disagree or disagree) to start their own business.

Age

A cross tabulation between age and entrepreneurial inclination indicated that almost half $(49.1 \%)$ of the youngest category of respondents (between 20 and 29 years old), had an inclination to start their own business. Among the slightly older age category (between 30 and 39) years of age), a much bigger percentage (72.8\%) indicated a similar inclination (Strongly agree or agree), whereas only $18.2 \%$ showed entrepreneurial disinclination. This means that entrepreneurial inclination was mostly exhibited among people between 30 and 39 years old.

\section{Gender and Marital Status}

A cross tabulation between gender and entrepreneurial inclination showed that $52.5 \%$ of female respondents had an inclination to start their own business, while $63.9 \%$ of the male respondents had this inclination. A similar cross tabulation between entrepreneurial inclination and the marital status of the respondents showed that about $67 \%$ of married respondents were entrepreneurially inclined, while $56 \%$ of single respondents were not. Both marital statuses show considerable inclination towards entrepreneurship. thus, a bigger percentage of male and married respondents showed entrepreneurial inclination than female or single ones, though all four category exhibited a relatively high tendency for starting a new business.

\section{Education}

Cross tabulation between education and entrepreneurial inclination showed that the education level of the respondents was not necessarily related to their tendency to start a business. For example, 58.9\% of respondents with only a high school certificate were positively inclined, while $55.7 \%$ of the respondents with a college degree were similarly inclined.

\section{Employment Status}

The respondents' employment status seemed to showed different results: about $48 \%$ of the unemployed respondents showed entrepreneurial inclination, while about $68 \%$ of employed respondents showed similar inclination. This result is interesting because respondents who already have jobs had more inclination to start their own business than those who were unemployed.

\section{Income}

Cross tabulation between income and entrepreneurial inclination revealed an unpredicted trend. Only $50 \%$ of the low-earning respondents (below $\$ 500$ ) indicated entrepreneurial inclination, though they had the biggest motive to do so; a similar percentage was indicated by respondents earning between $\$ 500$ and $\$ 1,000$; however, as income increased ( $\$ 1,000$ - $\$ 500)$ indicated entrepreneurial inclination, though they had the biggest motive to do so; a similar percentage was indicated by respondents earning between N500 and N1;000; however, as income increased (\#1,000-\#3,000), so did entrepreneurial inclination: (72.8\% of this income category were positively inclined). These results emphasize the pull factor (attractiveness of entrepreneurship) as opposed to the push factor (Obligation to start a business) in entrepreneurial inclination, both of which will be explained thoroughly in the interpretation section.

\section{Statistics}

Analysis of variance was performed on the demographic variables as independent variables, and entrepreneurial inclination as the dependent variable. The results of the analysis show that none of the demographic variables has a statistically significant impact on entrepreneurial inclination except for income. Income was the only demographic variable with a statistically significant F-statistic (Sig. $0.028<0.05)$ 
Table I. Demographic characteristic of the respondents

\begin{tabular}{|c|c|c|}
\hline Variable & Frequency & Valid Percentage \\
\hline \multicolumn{3}{|l|}{ Age } \\
\hline $20-29$ & 57 & $56.4 \%$ \\
\hline $30-39$ & 33 & $32.7 \%$ \\
\hline $40-49$ & 9 & $8.9 \%$ \\
\hline 50 and above & 2 & $2 \%$ \\
\hline \multicolumn{3}{|l|}{ Gender } \\
\hline Males & 61 & $60.4 \%$ \\
\hline Females & 40 & $39.6 \%$ \\
\hline \multicolumn{3}{|l|}{ Marital Status } \\
\hline Single & 68 & $67.3 \%$ \\
\hline Married & 31 & $30.7 \%$ \\
\hline Divorced & 2 & $2 \%$ \\
\hline \multicolumn{3}{|l|}{ Education } \\
\hline High School & 34 & $33.7 \%$ \\
\hline BA degree & 61 & $60.4 \%$ \\
\hline MA/MS & 5 & $5 \%$ \\
\hline $\mathrm{PhD}$ & 1 & $1 \%$ \\
\hline \multicolumn{3}{|l|}{ Employment } \\
\hline Unemployed & 27 & $26.7 \%$ \\
\hline Employed & 47 & $46.5 \%$ \\
\hline Business owner & 23 & $22.8 \%$ \\
\hline Seriously considering starting own biz & 4 & $4 \%$ \\
\hline \multicolumn{3}{|l|}{ Income } \\
\hline Below 00 & 12 & $11.9 \%$ \\
\hline$\$ 500-\$ 1000$ & 47 & $46.5 \%$ \\
\hline$\$ 1001-\$ 3000$ & 33 & $32.7 \%$ \\
\hline$\$ 3001-\$ 5000$ & 5 & $5 \%$ \\
\hline Above $¥ 5000$ & 4 & $4 \%$ \\
\hline
\end{tabular}

ANOVA

Table II. ANOVA Table for income and Entrepreneurial Inclination

\begin{tabular}{|l|l|l|l|l|l|}
\hline & Sum of Squares & Df & Mean Square & F & Sig. \\
\hline Between Groups & 18.930 & 4 & 4.732 & 2.839 & .028 \\
Within Groups & 160.021 & 96 & 1.667 & & \\
\hline Total & 178.950 & 100 & & & \\
\hline
\end{tabular}
inclination.

From the above table, income is a significant demographic variable that affects entrepreneurial 
Table III: Factor analysis of barriers to entrepreneurship

\begin{tabular}{|c|c|c|}
\hline Factors & Items & Factor Loading \\
\hline 1. Social Network & $\begin{array}{l}\text { Support from community, family \& friends } \\
\text { Entrepreneurs feel they can overcome risk } \\
\text { Social network helps entrepreneurs } \\
\text { Eigenvalue } \\
\text { Variance explained }\end{array}$ & $\begin{array}{l}0.564 \\
0.537 \\
0.514 \\
2: 325 \\
11.625 \%\end{array}$ \\
\hline 2. Fear of Failure & $\begin{array}{l}\text { One reason behind lack of entrepreneurship is fear } \\
\text { of failure. } \\
\text { No good balance between work and personal life } \\
\text { Eigenvalue } \\
\text { Variance explained }\end{array}$ & $\begin{array}{l}0.603 \\
0.345 \\
1.795 \\
8.973 \%\end{array}$ \\
\hline 3. Business Environment & $\begin{array}{l}\text { Existence of community support } \\
\text { Environmental stability } \\
\text { Active funding programs } \\
\text { Eigenvalue } \\
\text { Variance explained }\end{array}$ & $\begin{array}{l}0.390 \\
0.443 \\
0.314 \\
1.603 \\
8.016 \%\end{array}$ \\
\hline 4. External Stability & $\begin{array}{l}\text { Economic stability } \\
\text { Political Stability } \\
\text { Eigenvalue } \\
\text { Variance Explained }\end{array}$ & $\begin{array}{l}0.824 \\
0.300 \\
1.439 \\
7.194 \%\end{array}$ \\
\hline 5. Lack of Resources & $\begin{array}{l}\text { Difficulty raising funds } \\
\text { Eigenvalue } \\
\text { Variance explained }\end{array}$ & $\begin{array}{l}0.850 \\
1: 388 \\
6.939 \%\end{array}$ \\
\hline 6. Aversion to Stress \& Hard & $\begin{array}{l}\text { Intimidated when work is stressful \& hard } \\
\text { No work/life balance } \\
\text { Eigen value } \\
\text { Variance explained }\end{array}$ & $\begin{array}{l}0.829 \\
0.254 \\
1.289 \\
6.446\end{array}$ \\
\hline 7. Aversion to Risk & $\begin{array}{l}\text { Risk prevents entrepreneurs from starting their own } \\
\text { business } \\
\text { Entrepreneurs are intimidated by risk related to } \\
\text { new hısiness } \\
\text { Eigenvalue } \\
\text { Variance explained }\end{array}$ & $\begin{array}{l}0.790 \\
0.543 \\
1.288 \\
6.440\end{array}$ \\
\hline $\begin{array}{l}\text { 8. Lack of Preparation and } \\
\text { Training }\end{array}$ & $\begin{array}{l}\text { Lack of flexibility \& adaptability to changes facing } \\
\text { new business } \\
\text { Eigenvalue } \\
\text { Variance explained }\end{array}$ & $\begin{array}{l}0.905 \\
1.108 \\
5.540\end{array}$ \\
\hline
\end{tabular}

\section{Model Summary}

\begin{tabular}{|l|l|l|l|l|}
\hline Model & $\mathrm{R}$ & R Square & $\begin{array}{l}\text { Adjusted R } \\
\text { Square }\end{array}$ & $\begin{array}{l}\text { Std. Error of the } \\
\text { Estimate }\end{array}$ \\
\hline 1 & $.795^{3}$ & .632 & .604 & .84134 \\
\hline
\end{tabular}

Table IV. Model Summary for regression eqution. 


\begin{tabular}{|l|l|l|l|l|l|}
\hline \multicolumn{2}{|l}{ ANOVA $^{\mathbf{b}}$} & Df & $\begin{array}{l}\text { Mean } \\
\text { Square }\end{array}$ & F & Sig. \\
\hline $\begin{array}{l}\text { Megression } \\
\text { Residual }\end{array}$ & 113.286 & 8 & 14.161 & 19.840 & $.000 \mathrm{a}$ \\
Total & 65.664 & 92 & .714 & & \\
\hline
\end{tabular}

Table V. Dependent Variable: Entrepreneurial inclination

Table VI. Regression table indicating the predictive ability of these barrier factors on entrepreneurial inclination Coefficients $^{\text {a }}$

\begin{tabular}{|c|c|c|c|c|c|}
\hline & \multicolumn{2}{|c|}{ Unstandardized Coefficients } & \multirow{2}{*}{$\begin{array}{l}\text { Standardized } \\
\text { Coefficients } \\
\text { Beta }\end{array}$} & & \multirow[b]{2}{*}{ Sig. } \\
\hline Model & $\mathrm{B}$ & Std. Error & & $t$ & \\
\hline 1 (Constant) & 3.554 & .084 & & 42.283 & .000 \\
\hline Social Network' & .964 & .084 & .720 & 11.406 & $.000^{*}$ \\
\hline Fear of Failure & -.019 & .084 & -.014 & -.222 & .825 \\
\hline Business Environment & .163 & .084 & .122 & 1.932 & .056 \\
\hline External Stability & .283 & .084 & .211 & 3.346 & $.001^{*}$ \\
\hline Lack of Resources & 0.41 & .084 & .030 & .483 & .630 \\
\hline Aversion to Stress and Hard & .037 & .084 & .028 & .438 & .662 \\
\hline $\begin{array}{l}\text { Hand Work } \\
\text { Aversion to Risk }\end{array}$ & & & & & \\
\hline Lack of Training and & -.302 & .084 & -226 & -3.576 & $.001^{*}$ \\
\hline Preparation & -.056 & .084 & -042 & -.666 & .507 \\
\hline
\end{tabular}

From the above table, it is obvious that these factors, social network $(\beta=.72, \mathrm{P}<.001)$, external stability $(\beta=.21, \mathrm{P}<.001)$ and lack of training $(\beta=-.22, \mathrm{P}<.001)$ are significant factors predicting entrepreneurial inclinations.

\section{Findings}

The research which was quantitatively based provided a good platform for the researchers to have an indept knowledge on how to use factor analysis in determining barriers to entrepreneurship endeavours. From the study the following findings were made:

1. Level of income of participants is a barrier to entrepreneurial inclination.

2. Social network is an important factor that hinders the ability to engage in entrepreneurial skills.

3. The external stability of the economy and polity hinders or motivates people from engaging in entrepreneurial endeavors.

4. Lack of training is also a barrier to entrepreneurial excellence.

\section{Conclusion}

From the findings, it becomes necessary to take a cursory look at these barriers and make a policy to address them if there will be a change in raising the entrepreneurial intents and abilities of young people. This will be necessary to help promote the economy and foster growth which will provide jobs and alleviate poverty. It is imperative to note that the level of education of the respondents was not necessarily related to their tendency to start a business.

\section{References}

[1]. Aldrich, H.E. (2000). Organizations Evolving. Sage, Newbury Park, C.A

[2]. Alain, Fayolie. (2003). EMPLOY on Business School

[3]. Gem Global Report. (2011). Global Entrepreneurship Monitor. www.gemconsortium.org

[4]. Hair, J., Bush, R., \& Ortinau, D. (2008). Marketing Research. McGraw, Hill/Irwin NY

[5]. Krueger, R. C. (2000). Competing Models of Entrepreneurial Intentions. Journal of Business Venturing, 15, 5, 411-532.

[6]. Mariotti, G. (2012). Entrepreneurship and Small Business Management. Prentice Hall.NJ

[7]. Nunnally, J.C. (1978). Psychometric Theory, 2ed. McGraw Hill, NY.

[8]. Taormina, R.J. \& Lao, S.K.M. (2007). Measuring Chinese Entrepreneurial motivation

[9]. Personality and environmental influences. International Journal of Entrepreneurial Behaviour \& Research, 13,4,.200-21. 